\title{
The cultural paradiplomacy of Barcelona since the 1980s: Understanding transformations in local cultural paradiplomacy
}

\author{
Mariano Martín Zamorano \\ Arturo Rodríguez Morató \\ CECUPS- Centre for Research on Culture, Politics and Society \\ Department of Sociological Theory - University of Barcelona \\ Office: $+34 / 934034897$ \\ marianozamorano@ub.edu
}

\begin{abstract}
This article seeks to explain the conditions for the emergence and institutionalization of the cultural paradiplomacy of the city of Barcelona and its local effects. The recognition of the city as an active participant on the international stage is based on its evolution from an industrial to a service economy. Against this backdrop, Barcelona's city council, in common with many other city authorities operating in the world's metropolises during the 1980s, initiated its own cultural paradiplomacy as a strategy for attracting capital and promoting local development. This policy became established as part of a new multi-level system of governance. This article analyses the causes of the institutionalization of this activity from an intergovernmental perspective. It concludes that in the context of economic globalization, the emergence of cities' cultural paradiplomacy is strongly related to the restructuring of the State and its external administration and to the intensification of the "cultural branding" of cities as a tool for global competition.
\end{abstract}

Keywords: cultural paradiplomacy, city branding, Barcelona, Catalonia, Spain. Word count: 8436 


\section{Introduction}

The foreign policies of city administrations today are an important element in the internationalization of both nations (Brenner 2004) and regions (Keating 2005). At the same time, the decentralization processes initiated by many countries have fostered the proliferation of relations between sub-state governments and an array of actors and organizations at the supra- and sub-national levels (Castells 2009, Duchacek et al. 1998, Preteceille 1994, Sassen 2007). As part of this reconfiguration that began during the 1980s, cities have steadily increased their level of intervention in the international arena and in the establishment of global networks (Castells 1993, Harrison 1995). However, the development of cities' foreign cultural policy represents a challenge to the traditional understanding of diplomacy ${ }^{1}$ and, as such, for the political construction of a coordinated and persuasive representation of the nation-state.

Foreign policy today is characterized by what has been described as "multilayered diplomacy" (Hocking 1993, p.3). This implies the participation of actors at sub-national levels in international relations, in what Duchacek (1990) has called parallel or "paradiplomacy". However, the nature of this participation differs depending on the sub-national level involved. The paradiplomatic activity of regional governments has been explained in terms of such variables as nationalism, the decreasing power of the State in matters of market regulation (Lecours and Moreno 2003) and new forms of social participation (Bélanger 1994). But the causes and characteristics of the cultural paradiplomacy of cities, barely studied to date, appear to differ.

This article therefore aims to contribute to the analysis of these local international policies. In seeking to shed further light on them, we study the case of the cultural paradiplomacy of the city of Barcelona and its relations with the external cultural action of both the central State and the (regional) Catalan government (the Generalitat). The Barcelona case is particularly significant in this respect owing to the importance attached to international elements in the city's cultural policy and the contentious implementation of various contradictory projects in the development of that policy. Here, we provide an interpretation of the institutionalization of cultural paradiplomacy in Barcelona from a historical and multi-level perspective by conducting an analysis that reveals the elements responsible for the establishment of this policy. Additionally, the analysis helps to clarify the dynamics to which this policy has given rise in the local political domain. Finally, it also contributes to identifying what underpins clashes between the city's image as projected in the international arena and 
city images that emerge at the local level from different urban social processes. Ultimately, our analysis should pave the way for future comparative studies in this field.

Since the 1980s, various local processes, including the boom in tourism and increasing social gentrification, have called into question the methods and goals of paradiplomacy, bringing them into direct confrontation with other internationalization strategies, such as cultural branding and policies for promoting tourism. These two ways of conceptualizing and projecting the culture of Barcelona have had a marked impact on the definition of the city's singular character. As such, Barcelona's heritage has typically been interpreted in two contrasting ways: one traditional (or nationalistic), the other cosmopolitan. These two identities have been defended by agents with an array of ever-changing goals. In this article, we show how control over the international image and the local heritage of Barcelona, currently transformed in an important symbolic capital, has been a constant point of contention. This has come about as a result of their capacity to generate political and economic benefits through branding processes, as symbols of national identities, as well as their being instrumental in upholding partisan interests.

\section{Cultural diplomacy, branding and the intensification of paradiplomacies}

Public diplomacy, or "public opinion diplomacy" as it was known during the postwar, is the practice by which relations are established between governments, people and civil organizations abroad (Mannheim 1994). For Cull it is "an international actor's attempt to manage the international environment through engagement with a foreign public." (2009, p. 12), while, today, as Zaharna (2009, p.86) points out, approaches to public diplomacy might range from propaganda to nation branding, to cultural programs. In this regard, cultural diplomacy has generally been defined as a subgroup of public diplomacy.

Cultural diplomacy has gained renewed prominence in recent decades in the wake of economic and social transformations in the cultural sphere. This somewhat fuzzy policy, designed by governments and implemented by diplomats, targets foreign audiences as well as other governments (Bound et al. 2007, p.21, Garcha 2007). It was shaped at the end of the $19^{\text {th }}$ century, with the creation of such institutions as the Alliance Française (1883) and the first postcolonial attempts of European liberal elites to expand their influence through symbolic capital, above all via languages (Paschalidis 
2009). Initially, cultural diplomacy consisted solely of mechanisms of cultural exchange (such as those found in international networks, the dissemination of the arts and study trips), but it also rapidly became one of the tools of war propaganda (Arndt 2007). Today, the various definitions of cultural diplomacy all have in common the concept of the artistic and intellectual exchange between nations; yet, they all differ in their understanding of what culture is and in the goals they seek to fulfill (Arndt 2008, p. 31, Bélanger 1994, p. 422, Cummings 2003, p. 1).

Since the middle of the 20th century, the actors involved in cultural international relations have diversified markedly. Against the backdrop of the emergence of multilevel governance, the interrelations of transnational organizations at a range of different levels from the supra-national to the local level have served to emphasize the multifaceted character of these policies. Such sub-state external policies or paradiplomacies (Criekemans 2006) have been the subject of growing research interest, primarily in pluri-national States such as Belgium, Canada and the UK, and at both the regional (Massart-Piérard 1999, Lecours 2002, Paquin 2004) and city levels (Milani 2010, Nunes 2005). However, to date few studies have been made of cities' cultural paradiplomacy and there have been few attempts to examine the relations between this kind of paradiplomacy and other cultural policies at the local level. All in all, this represents a great deficit, since local cultural policies have acquired considerable importance in recent decades (Bianchini 1993, Menger 2010) while, at the same time, their international component has gained in prominence (Negrier 1997).

Any examination of local cultural policy needs to distinguish between cultural paradiplomacy and the one-way flow communication strategy of branding. These two practices are often confused, both in terms of their theoretical and practical characteristics, because one of the bases for creating a territorial brand (besides tourism, exports or governance) is the culture of a place (Anholt 2006). But while cultural paradiplomacy acts as an instrument to project heritage and diversity by adopting a relational approach, branding is applied to different political territories so as to promote a particular, and usually, homogeneous image, with the aim of reaping economic benefits. City branding has been practiced since the nineties as part of the so-called 'entrepreneurial turn' in local policy (Harvey 1989, Kotler et al. 1993). And while it is sometimes considered a public channel for disseminating information as a common good (Leonard 2002), city branding is increasingly being designed by consultant offices 
and private companies (Aronczyk 2008). Thus, in practice, it is characterized by a somewhat limited social participation.

Here, therefore, we adopt an approach that clearly differentiates between branding and foreign cultural policies and seek to further the analysis of paradiplomacies in the cultural area.

\section{Contextualization of cultural paradiplomacy in Barcelona}

Spain's transition to democracy was characterized by a process of decentralization of its legal and administrative systems, resulting in a quasi-federal scheme of government known as the "State of Autonomies" (Aja 2007). This was established in 1978 along with the National Constitution and the subsequent enactment of the Statutes of Autonomy, which created seventeen Autonomous Communities and two autonomous cities as Spain's first-level political division. Three of these communities, Catalonia, the Basque Country and Galicia, were given the status of "historic nationalities" (Art. 2) and established their own co-official languages. Nationalist movements in these regions first emerged in the $19^{\text {th }}$ century, but over the course of the following century they were repressed by the centralist, mono-cultural dictatorship that ruled the country between 1939 and 1975.

Following the transition and the establishment of the State of Autonomies, which recognized the country's cultural and political diversity, greater demands for autonomy were made. The organization of the State system came to be characterized by the multiple tensions between the different nations making up the State and the central government. Indeed, the country's plurinational and plurilingual character gave shape to the decentralization of State cultural policy (Rubio 2008) and, among other far-reaching transformations, favored the delegation of most aspects of cultural management (including museums, libraries and the performing arts) to these governments in the autonomies. In Catalonia, where previously many cultural projects had been blocked by the repressive dictatorship of General Franco (Bonet 2001), the path was now clear to develop a cultural policy oriented towards the promotion of Catalan identity (Villarroya Planas 2011).

While according to the National Constitution international relations are the exclusive competence of the central State (Art. 149), the various legal reconfigurations and the delegation of competences to the Autonomous Communities that formed part of 
the decentralization process opened the door to sub-state foreign policies. This paradiplomacy was further enhanced by Spain's accession to the European Union in 1986. Most notably, Catalonia has been able to promote its cultural paradiplomacy by building an institutional structure that today has significant reach for a sub-state framework. ${ }^{2}$ This process has been expanded since the 1990s in the context of a broad consensus across the political spectrum with regard to its importance for regional progress. Moreover, during certain political periods, these tools have been seen to be critical for obtaining international recognition of the distinctiveness of Catalonia in the face of Spanish foreign policy and identity, ${ }^{3}$ reflected in a lack of systemic organization and representational differentiation and the absence of any programmed coordination between the external cultural actions of the Catalan and Central governments.

At the same time, the Barcelona City Council ${ }^{4}$ has also built up a government structure to promote its own cultural paradiplomacy and it has formulated a specific program to stimulate transnational relations and to create networks via its cultural activities. This policy constitutes very much part of the city's internationalization process. Barcelona's increasing projection has resulted in a patent "transcending" of negotiations between Catalonia and Spain as it has shown great aptitude for promoting its own culture worldwide, becoming in the process one of the most visited cities in Europe. ${ }^{5}$ On the other hand, its status as "capital" constituted part of an extended dispute between the city's socialist administration (1979-2011) and CIU, a nationalist right-wing coalition that headed the Generalitat (Catalan government) between 1980 and 2003 (Bouzada 2007, Bonet 2001, Gabancho 2009, Marzo and Badia 2006, p. 17). This was due largely to discrepancies regarding the role the city should play in representation of Catalonia and the function it should fulfill in a nationalist political project. In this regard, we shall show how the cultural projection of Barcelona , represented a challenge with respect to its political capitalization and associated social effects and those processes linked to its representational association with Catalan and Spanish identities.

\section{The establishment of Barcelona's cultural paradiplomacy: from the Olympic Games to the creation of ICUB}

The consolidation of the city of Barcelona as a global icon has been based on a farreaching public intervention in the cultural field and on a process of urban regeneration, 
which also involved a major social overhaul. This process was initiated in 1979 by the Socialist Party of Catalonia ${ }^{6}$ (PSC) (Subirats and Brugue 1997) under the leadership of the city's former Mayor, Pasqual Maragall (1982-1997), who left a strong personal mark on the city's infrastructure and cultural panorama. Maragall developed a civic discourse that manifested specific representations of Barcelona's personality. According to McNeill (2001), in reference to a concept forwarded by Benedict Anderson, his discourse allowed the society of Barcelona to be considered as an "imagined community". It was an "identity generation" rooted in ideological precepts - a sort of "cosmopolitan left-wing nationalism", that gave "coherence to change" (McNeill 2001, p. 4). Local culture and common heritage were the key elements that contributed to this metamorphosis and to the revitalization of the historical singularity and avant-garde character of the city (Mascarell, 2007).

The urban reforms had been initiated earlier by socialist mayor Narcís Serra (1979-1982) and his so-called policy of 'darning' urbanism (Maragall 1992). They were continued with a campaign aimed at revamping the city's private heritage under the slogan Barcelona posa't guapa! (Barcelona, make yourself beautiful!), which was launched in 1985 and comprised a system of public funding for the private sector aimed at rehabilitating and improving the aesthetics of the city's residential heritage. The process went hand in hand with arrangements for the 1992 Olympic Games, set in motion some six years prior to the event itself. The Games, organized in partnership with the private sector ${ }^{7}$, were supported by all three tiers of government: the local, the regional and the central levels. The preparations for the '92 Olympics served to boost the institutionalization of official paradiplomacy in Barcelona, with the creation of the City Council's International Relations Department. Margarita Obiols, former Director of the Department, has said in this respect:

"This was initiated in 1986 with the nomination of Barcelona as an Olympic city. In 1987, following the elections, it was decided to create an international relations team and three regional priorities were established: Europe, Latin America and the Mediterranean. At the same time we sought to maintain an active presence in international organizations” (Marx 2008, p. 90). 
As part of this process, the city council adopted an extensive agenda dedicated to public paradiplomacy and making the city internationally visible (Garcia, 2002). To this end, specific structures of cultural paradiplomacy were created. Before and after the games, it was decided to promote what became known as the Cultural Olympiad. To this end, in 1998 the city council created the firm, Olimpiada Cultural SA (OCSA), a public-private partnership that operated separately from the city's Olympic organization. It was headed by the city mayor and managed by various public and private sector agents. OCSA organized a program of cultural events entitled the "Year of Sport" (1989), the "Year of the Arts" (1990), the "Year of the Future" (1991) and, finally, in 1992 the "Olympic Festival of the Arts" (Moragas i Spà 2008). However, the organization's operations were characterized by constant disputes with the various tiers of government. Thus, owing to political discrepancies, the agreement between the city council and the Catalan Department of Culture to promote the above program of cultural years was not signed until 1991. Interestingly, the Games' opening and closing ceremonies included symbolic elements of Catalonia and, to a lesser extent, integrated certain symbols of Spain (Moragas i Spà 2012, 2008).

After the Olympic Games, Pasqual Maragall wrote (1992, p. 7) in reference to the potential achievements of the city: "International interests, tourism and business investment, will be, without doubt, other positive factors in Barcelona 1993." Indeed, Maragall's international and pro-European vocation was subsequently reflected in his continuing political efforts to promote the city's paradiplomacy. ${ }^{8}$ Thanks to these initiatives, his government demonstrated a great capacity to manage the dialectic of local and international policy. This entailed the deliberate use of international voices as amplifiers of local interests and of homegrown processes integrated within international networks and dynamics. It is these processes that we believe contributed to the consolidation of Barcelona as an international cultural center (Subirats and Brugue 1997, p. 261, Subirós 1994).

In the wake of the Games, the city council undertook an ideological and organizational reconsideration of its cultural policy. This also implied the autonomization and diversification of its public intervention in cultural actions abroad. While various actions continued to make up the programs directed by the City Council's International Relations Department, new developments were made. ${ }^{9}$ In 1996, Barcelona's Institute of Culture (ICUB) was created. This public agency, designed by Ferrán Mascarell, a historian and one of the ideologues of the Barcelona model, 
integrated the city's various cultural management offices. Today, ICUB promotes cultural policies by adopting an entrepreneurial approach and by managing the city's multiple facilities and its cultural actors. Mascarell established the organization with a group of professionals who were also engaged in seeking to get Barcelona nominated as the European Capital of Culture 2001; a project that would later be abandoned. Thus, ICUB was founded with the idea of pursuing two goals: the revitalization and the internationalization of the city's culture. The institution has made a great contribution to international cultural activity, ${ }^{10}$ the promotion of arts and art events in the territory, and it has actively participated in international cultural networks. Furthermore, in 1996 ICUB set up the Barcelona Plató Film Commission, aimed at promoting the production of movie making in the city by offering financial support and other technical advice.

\section{Barcelona's cultural paradiplomacy and city branding since 1999}

Although Maragall stood down in 1997, the PSC continued to govern Barcelona until 2006. In 1999, Ferrán Mascarell, former director of ICUB, was appointed City Councilor for Culture and the city's 'Strategic Plan of Culture' was presented that same year. This emerged after a period in which the city's cultural policy was the subject of much rethinking on the part of the many actors operating in the cultural field, concerned by the low rates of participation of Barcelona's citizens in the local offer (Obiols, 1998) and by the first signs of the undesired effects of internationalization.

During the 1990s the city government had promoted a range of programs aimed at internationalizing the Barcelona image, in which foreign policy served as a tool for accomplishing specific political, urban and social goals. In contrast, the new decade was to be more closely associated with an economic turn in local cultural policy, characterized by the provision of more space of action in which private capital might operate and the promotion of the "city's cultural thematization" (Casellas et al. 2010, Rodríguez Morató 2005). In this vein, the Barcelona Plató Film Commission has been identified as acting as an "instrument of propaganda" in the diffusion and naturalization of the aestheticization of the urban space and of a politically constructed image (Balibrea 2005). But while the local administration has been characterized by its concern for social participation (García 2008, Subirós 1999, p. 28), its policies have also been criticized for their excessive attention to tourism (Bonet 2001; Casellas et al. 2010) and for a range of diverse outcomes, including the adaptation of urban areas to 
marketing strategies and to previously projected images, and increasing rates of gentrification and cultural homogenization ( Capel 2007, McNeill 2001, Nofre i Mateo 2010, Palou 2009). In this emerging context, the city council seemed to have developed an approach to paradiplomacy that differed from that of satisfying social 'needs'. As a Barcelona opinion leader has said: "not all internationalization implies the dignifying of culture. Many elements such as the appeal to kitsch, giving backing to formal grandiloquence and mannerism lead to tourism but not to cultural internationalization."(Ramoneda 2011, p. 50). Incidentally, at this juncture, the importance of the Barcelona brand, exploited now by diverse sectors within the administration, including the tourism and finance departments, and the growing intervention of private actors, had a marked influence on Barcelona's cultural policies.

In this sense, the paradiplomatic activity of the city council began to reveal the tensions between a public paradiplomacy focused on branding and the approach favored by the ICUB which, in the words of its policy adviser, Esteve Caramés (pers. comm., 19 Sept. 2013), was oriented more towards the promotion of local art. Yet, ICUB's cultural policy continued to show a concern for internationalization. Indeed, the 1999 Strategic Plan of Culture highlights this dual focus: on the one hand, the importance of culture as an element of development and social cohesion; and, on the other, as is pointed out in the Plan: "Barcelona can promote its role as cultural capital of Catalonia, as the cultural co-capital of the Spanish State and as one of the cultural capitals of Europe with the greatest opportunities of self-projection." (ICUB 1999, p. 4). Moreover, the Plan endorses a policy of internationalization based on networks, trade fairs and meetings in order to create the conditions to attract creative minds and to diversify the cultural offer in coordination with the tourist sector. The main strategies of cultural internationalization continued to be the organization of major events, the promotion of the cultural industries and the taking of an active, pioneering role in city networks and supranational organizations (Castells and Ollé 2004, p. 13). Thus, for example, in 2002 Barcelona organized the Eurocities Culture Forum ${ }^{11}$. At the same time, it has signed a large number of agreements with cities and bodies around the world to promote culture. ${ }^{12}$

In a similar vein, Barcelona, in an effort at renewing the city's Olympic spirit, undertook the organization in 2004 of a highly significant project promoted by the then President of Catalonia, Pasqual Maragall: the Universal Forum of Cultures. The Forum was a joint undertaking of the city council, the Generalitat (since 2003 both authorities 
were controlled by the Socialist Party), Spain's Central Government and UNESCO. The event integrated all the city's main cultural amenities and counted on the active involvement of various social organizations. Its program was centered on three main issues: support for peace, sustainable development and cultural diversity. The objectives of the Forum were to promote social debate and to create a space in which the international dimension of these three issues might be debated and their problems addressed. This latter goal gave the Forum an "intrinsically international character" (Rodríguez Morató 2005, p.369). However, the project came in for fierce criticism owing to the concomitant urban speculation and the lack of social involvement (Acebal 2008). Ferrán Mascarell was particularly skeptical about the event given its inability to involve the local community (Caramés, pers. comm., 19 ${ }^{\text {th }}$ Sept. 2013) and he would subsequently refer to it as a 'failure', because in its organization "culture lost out to short-term politics" (Serra 2008). As part of the reconsideration of the Barcelona model following the Forum, a new Strategic Plan of Culture was drawn up in 2006. The new Plan recognized the need for the city's cultural policy to tackle the emerging effects of globalization in the urban environment, including immigration and cultural diversity. Moreover, it emphasized the importance of being competitive on these issues in relation to other cities (Barcelona 2006, p. 14). One of its proposals was to highlight various projects centered on Barcelona as a Cultural Capital, such as the rehabilitation of its cultural amenities and the need to host international events.

The cultural paradiplomacy of the city of Barcelona today is a transversal activity so that a significant part of the ICUB's structure (divided in seven divisions) is concerned with cultural internationalization. For example, the division for the Promotion of Cultural Sectors, which manages the Catalonia-Barcelona Film Commission, undertakes many actions of internationalization via its so-called Creation Factories (ICUB 2012, p. 20). The factories comprise various sites, located in postindustrial buildings in different city neighborhoods, for the production of the visual arts, which attract creative minds from around the world and organize events via the international networks. One of the other divisions, that of Local Culture, organizes the traditional city fiesta of La Mercè celebrated in September, which today is an international event with artists performing from around the world in a range of activities that include dance, concerts, and the visual arts. In 2012, 1.4 million people participated in the fiesta (ICUB 2012). ICUB's work in the city's international projection and its cultural cooperation program, managed by the Barcelona Capital division, includes a 
group of projects specifically aimed at promoting cultural internationalization. For example, the Grec Festival is an international point of reference in the fields of dance, circus, music and theatre. The international work of the ICUB is today complemented by its growing exploitation of its on-line resources used for example in promoting its Creation Factories (ICUB 2012, p. 20) and disseminating information about the Grec Festival via an interactive program called “Grec Innovates” (ICUB 2012, p 37).

In 2012, ICUB employed around 424 civil servants and its general budget amounted to 117 million Euros (ICUB 2012). Given the transversal nature of cultural paradiplomacy, it is not easy to identify the specific amount of human and economic resources allocated to cultural internationalization. However, the international dimension is evident in many of the ICUB's activities and one of its priorities is to "boost the international projection of the agents that form part of the city's cultural system" (ICUB 2012, p. 38).

\section{Table 1. Main activities in the cultural paradiplomacy of ICUB (2001-2010)}

In short, the city council's foreign activity comprises a diverse range of artistic exchanges and cultural network projects that coexist with branding and major cultural events. These latter strategies seem to have promoted top-down policies, in which social organizations have made only a limited contribution. ${ }^{13}$ Nonetheless, there would seem to be a growing market presence along with the closer involvement of different actors from civil society in the development of the city's cultural paradiplomacy. From a historical perspective, even the large-scale events have been characterized by a segmented social participation during their design, organization and aftermath. Moreover, the city's cultural organizations have been actively involved in cultural and artistic activities abroad so that today multiple associations from Barcelona's cultural tertiary sector participate in actions outside the country (Fina and Subirats 2011).

\section{The emergence of cities' cultural paradiplomacy}

As discussed above, city governments have introduced new modes of external influence and, as a result, have modified their traditional role in this arena. The outcome is that cities' cultural paradiplomacy has gradually gained in autonomy and its capacity to act. 
Below we examine the macro variables that account for this development and discuss their relation to the case of the city of Barcelona. The first factor is undoubtedly the position acquired by culture in contemporary societies, characterized by the growing significance attached to cultural goods, services and representations as essential elements of modern-day society and to their public management in a post-Fordist age. This phenomenon is closely linked to changes in the social organization of the arts and to the multiple changes in cultural production and consumption (Rodríguez Morató 2012, 2007). In this new setting, culture has become a central element of political struggle and economic competition. The recovery of autonomous government and the major social transformation in Catalonia initiated with the transition towards democracy have been instrumental in shaping this cultural shift. As Flaquer and Giner (1992) have stressed: "In Catalan society, culture has gradually become a crucial entity of the collective consciousness, and one that has been intensely politicized. An entity that is most clearly polysemic and polyvalent." This process has been inextricably associated with the particular significance afforded to culture, subject as it has been to a programmatic substantiation and restoration, and used as an instrument for the legitimization of divergent political projects (Giner 1996). Against this sociopolitical backdrop, the culture and image of Barcelona have become invaluable capital for public management.

Second, state regulation and globalization have changed the structure of public authority (Jessop 1997). In turn, this change in political direction, characterized by the internalization of "the trans-boundary function" (Sassen 2007) of the State, has resulted in various geopolitical transformations. It is a process that has seen a shift from government to systems of governance and the transfer of state power to sub- and supranational institutions (Jessop 1997, p. 32). In this post-Fordist framework, cities have become renewed political and economic actors. For example, as Evans (2003, p.12) describes, the regional organization promoted by the European Union since the eighties has favored the leadership of cities: "Politically, this has also empowered city authorities over central and even regional ('meso')tiers of government". These changes served to promote competition between cities in their attempts to attract investment and to boost the participation of the private sector in issues of cultural policy. This is clearly reflected today in the proliferation of international urban art festivals and performances and the profusion of transnational organizations of cities and global networks. In this respect, the development undergone by Barcelona's cultural paradiplomacy is especially 
representative of the restructuring in the inter-scalar administration of culture over the last few decades.

. Another feature of this transformation has been the convergence process entered into by cities with regard to their branding and cultural paradiplomacy. This is well illustrated by the cities of Paris and Berlin ${ }^{14}$. Many cities, using cultural management and similar strategies of branding, pursue internationalization as a means of boosting their competitiveness and attracting capital (Zukin 1995, Bianchini 1993). The institutionalization of these practices is an organizational facet of the so-called 'entrepreneurial city', in which what were formerly national policies are now also being implemented "from below" (Jessop 1997, p. 35). In this regard, the "reterritorialization" that nations have been seeking to achieve through national branding techniques (Aronczyk 2009) proves to be more easily achieved by city governments. Today's city authorities enjoy many advantages over other political actors, including, for instance, the regions and provinces, and have access to the instruments that ensure they can fulfill the goals set in their external cultural policies. Cities today benefit from the concentration of different forms of capital and a great capacity for communication with a range of international sectors (Castells 1997). Moreover, they play host to a huge number of cultural agents and institutions (Rodríguez Morató 2005). Barcelona is a good example of this: witness, the way in which it has had the ability to create a "Bohemian brand", as in the case of the Raval city district (Rius 2013), and to develop its brand by exploiting the "comparative advantage" of the city's Modernisme architectural style (Balibrea 2007). In order to implement successful processes of heritagization and to offer a diversity of cultural goods and representations, the city is proving to be more attractive than the traditional idea presented by a homogenous image of national identity (Evans 2003, p. 7).

The final factor is the transformation recorded in local cultural policy in the framework of this new conceptual model. In this regard, the development of cities' cultural paradiplomacy can be seen as forming part of the local and entrepreneurial turn of cultural policy (Connolly 2011) and of its general redefinition (Cherbo and Wyszomirski 2000). Thus, we have witnessed a general tendency towards the diversification of the fields of cultural action and the incorporation of private actors and social organizations, with cultural policy being approached in systemic terms (Rodríguez Morató 2005, p. 370, Rius 2003, p. 4). As we have seen, attention to the "external view" is today an essential factor in the design of cultural policy (Aronczyk 
2008 , p. 44). The increasing organization of cultural paradiplomacy in a context of social legitimacy of internationalization policies affects the relation between local actors and, ultimately, it influences the forms of association between culture and policy. In this context, "scalar transformations in the territorial government" (Marshall 2004, p. 6) also promote the specialization of cultural paradiplomacy as a prized and shared instrument for diverse areas of urban governance. Likewise, it enabled various spheres of public administration to acquire expertise in aspects of external cultural policy, such as Diaspora policies and the creative economy. In this respect, there is a clear connection between foreign action and the adoption of local cultural policies and its agential conditions. Today, this orientation incorporates foreign activity as a significant area for cities" "cultural policy systems".

\section{Specific political conditions underpinning the development of Barcelona's cultural paradiplomacy development: cultural paradiplomacy in a "stateless capital"}

\section{Catalan cultural paradiplomacy and the State}

The organization of the contemporary system of governance implies a "reordering of the relationship between government and governance within the overall political system and (...) major trans-territorial and international governance mechanisms at regional and local level" (Jessop 1997, p. 33). In this regard, the politically managed reform of the state has paved the way for the increasing significance of cities in international relations and changes in the ways of government and competition at each State level. Hence, cities' “intermestic" (Duchacek 1984) policies (i.e., international + domestic) need to be analyzed in terms of the relations established between State political, legal and economic structures (Brenner 2003, p. 3). This we undertake to do below.

The end of the dictatorship in 1975 ushered in a period of extensive decentralization in Spain's external cultural activities. However, despite this, the system of cultural diplomacy has never been truly coordinated or systematized (Otero and Marco 2010, p. 7; Noya 2003, p. 6; Alonso 2004, p. 23; Colino 2007, p. 20). In this context, two possible interpretations might be made of the paradiplomacies of the Autonomous Communities: as an attempt to develop a policy for a quasi-federal and multi-national system or as an activity that supposes a "deconstructive dynamic" for the State (Armiñan 2004, p. 22). In this regard, Spain's Central government and the Generalitat, 
despite some common cultural projects overseas, have worked as differentiated and non-coordinated channels.

Over the last few decades, various attempts have been made to recentralize Spain's external policies or, alternatively, to provide a better balance in the competences of the Autonomous Communities. Indeed, following the resolution taken by the Constitutional Tribunal (2010) to limit proposed reforms to the Catalan Statute of Autonomy that would have increased Catalonia intervention abroad and various measures introduced by Spain's current conservative government (Anteproyecto 2013), the system has shown a marked trend towards recentralization. However, the legal and economic restrictions placed on the Autonomous Communities' exterior activity by the State, especially in the context of growing Catalan nationalism, appear to have boosted the importance of Barcelona in the projection of Catalan culture abroad and increased the city's competition with Madrid.

All in all, despite the decentralization of competences for cultural policy in Spain, the State has shown a clearly centralist conception of the capital's role in cultural policy (not unlike that manifest in France). Today, the bulk of funding from the Ministry of Culture targets major national cultural industries and events in Madrid (Cubeles 1993; Simon 2006). However, this is not to deny the capacity of Barcelona's city council to build certain alliances, targeting a range of goals, with both the State and Catalan governments thus providing the city with a variety of opportunities to promote its cultural internationalization, such as the use of different sources of economic and logistical resources in the city area. Thus, the trans-scalar character of Barcelona and its pending status as the capital of Catalonia (Mascarell 2007), a "stateless nation", have promoted different dynamics between the administrations. On this question, the Catalan Government's Foreign Action Plan (2010-2015) points out:

"The image that the Barcelona brand has, the role this plays in the city's international projection and its potential for the image of Catalonia should be borne in mind here. Barcelona undoubtedly serves as a catalyst for many positive elements for Catalonia as a whole and which we must learn to associate with different but inseparable realities. As such, we must learn how to activate the great potential of the Barcelona brand and to use it in a way that it can complement the image of Catalonia" (Departament de Vicepresidència 2010). 
This process of establishing a cultural projection from the conception of joint capital status in the context of a pluri-national State is comparable, to a degree, with the city of Montreal.

Montreal is the economic and administrative capital of Quebec, Canada's second largest province in terms of population, and capital of its francophone nation. Canada operates a federalist system of government that is considered respectful of its national and cultural diversity (Kymlicka 2003). The State's ten provinces enjoy responsibility for education and culture (Art. 93 of the Constitution) and, unlike Spain, foreign policy is not clearly defined as the exclusive competence of the central State (Nossal et al. 2007). As a result, Quebec, a province with a deeply rooted nationalist movement, has developed its own strong cultural paradiplomacy "as the extension of its internal cultural competences" (Gérin-Lajoie 1965) and as the representation of its singular identity (Bélanger 1994, p. 425). This policy has also been the subject of various processes of negotiation with the central government (Barba 2006, p. 135), and has been characterized by a similar international strategy to that adopted in Catalonia.

Like Barcelona, Montreal was governed for many years by a charismatic mayor, Jean Drapeau (1954-1957, 1960-1986), who promoted major international events (including the 1976 Montreal Olympics), instigated an urban regeneration program and fostered a cosmopolitan imaginary for the city (Germain and Rose, 2000, Gérin-Lajoie 1965, p. 579). From within his center-right party, Drapeau promoted a federal system for Canada and, in common with Maragall, supported the importance of the identity of Montreal, in this instance within francophone Canada, but he was opposed to any claims to sovereignty. Today, Montreal's cultural paradiplomacy is promoted by the Council of the Arts, which fosters the work of local artists and which organizes an internationally renowned program of spectacles, including it cinema and jazz festivals (Conseil des arts de Montréal 2012). One of the current objectives of the city council is to make Montreal a "leading metropolis of the arts on both the national and international stages" (Conseil des arts de Montréal 2012, p. 41). Moreover, the city has been defined as an active center for promoting Quebec's foreign cultural policies (Gouvernement du Québec 2006, p.87).

While the purpose of this study is not to make a detailed comparative analysis, a number of similarities between these two cities are worth stressing. In line with Lecours (2002) we should stress the importance of nationalism in accounting for regional paradiplomacy and for defining their identities, while the development of the two cities' 
external cultural policies needs to be seen in connection with the cultural competences enjoyed by other cities in their respective States.

\section{Barcelona's cultural paradiplomacy: between "cultures" and branding}

A second dynamic force in the definition and projection of Catalan culture is associated with the political struggle between the respective authorities of the city of Barcelona (the city council's cultural institutions) and the Generalitat, the government of the Autonomous Community (Moragas i Spà 2008). In this regard, Subirós (1993) stresses:

"Although the activity of the Generalitat is complex and, in many sectors, oriented towards modernization and economic competiveness, the ideological discourse of Jordi Pujol and a good part of his political strategy is based on a historicist, essentialist, ruralist and anti-metropolitan script that looks for and uses confrontation with Barcelona and the central government to confirm and reinforce the autonomy and competences of the Generalitat" (Cited in McNeill 1999, p. 67).

This political struggle has been typified by two dimensions. One of these was closely linked to the "search for attention" and attempts to internationalize the city via the projects developed during the 1980s. The other was linked to the "struggle to construct a perception" and was concerned with connecting the city's image and culture to the representation of a particular identity. In this framework, the power of the Barcelona image and its internationalization has come into clear conflict with Catalan culture and its identity. Yet, in practice, this tension between the Generalitat and the city council evolved over two decades within the context of a common Catalan nationalist ideology (Catalanisme) held by the region's two main political parties. Thus, in many instances, any controversy surrounding Barcelona's cultural projection was not underpinned by any disagreement as to the constitutive nature of its cultural policy but rather concerned the instrumentalization of artistic events and activities with an international presence and the management of local public opinion. In a similar vein, Jordi Pujol, the former president of Catalonia, has explained why the Generalitat's general commitment to the importance of the diffusion of Catalan culture in conjunction with Pasqual Maragall had to be modified in particular situations: 
"Maragall is a man of Catalan culture. But, at a given moment there were some differences, a certain distance between the Catalan culture being promoted from within the city council, by the Socialist Party and before that by the Communist Party, and us. There was some distance. But, at the end of the day, these differences were not important. They might arise at a given moment and might emerge as a problem of political leadership." (Jordi Pujol, pers. comm., $9^{\text {th }}$ Jan. 2013).

Subsequent to these tensions, the current conception of the city's cultural policy as held by the first Counselor of Culture to represent CiU, Jaume Ciurana, provides a new perception of Barcelona as the capital of Catalonia. In a conference held in October 2011 he outlined ICUB's new cultural policy. He argued that Barcelona should now: "exercise responsibly and uninhibitedly as the capital of Catalonia" (Ciurana 2011, p. 1), because: "we have played at being capital of many things, some more justified than others, but we forget that what makes Barcelona different from other cities is that Barcelona is the capital of a nation with its own culture." (Ciurana 2011, p. 2). Ciurana also warned of the risks of converting Barcelona into a 'non-place' by comparing the city with an airport waiting lounge. Likewise, he stressed: "Catalan culture does not have the power of a State behind it, but let it be known that the capital is prepared to put itself at the head" (Ciurana 2011, p. 3). In reference to the relations between the city and Catalonia, he asserted: "In recent years, there has been, culturally speaking, a disconnection between the capital and the country" (Ciurana 2011, p. 5). Echoing the thoughts of Ramoneda (2011), he noted that, even though the internationalization of Barcelona is an achievement, it is based on branding and not on the city's cultural heritage. To reverse this situation, the politician suggested, among other actions, linking the name of Barcelona with the "great names" of Catalan culture and taking measures to assimilate the city's immigrants and not allowing multiculturalism to fail as it patently has in other European capitals (Ciurana 2011, p. 13).

This process has recently seen the first steps being taken towards establishing a coalition in cultural paradiplomacy between the city and the autonomous community with the incorporation of Barcelona City Council on the board of the Ramon Llull Institute in 2014 (Ara Cultura 2014). In this new context of the same political party 
holding office in the Generalitat and in the city council, new dialogues on "Catalanisme" will no doubt be entered into.

However, a second element emerging is the new model of international cultural policy, which is generating a certain rhetorical and programmatic tension between the city council's projects that seek the economic promotion and branding of Barcelona, on the one hand, and ICUB's exterior actions, on the other (pers. comm., Jordi Pascual, ICUB 31 Jan. 2013). Here, a key independent variable is the prevailing relationship between public institutions and the local cultural arena and its actors in the creation and projection of a representation of the city. In this sense, Barcelona's cultural paradiplomacy evolved from the establishment of a specific structure designed to promote the city's internationalization, in the context of the Cultural Olympiad (1987) and based on the creation and restoration of the city's cultural infrastructure - with assets that quickly proved to be politically and economically profitable, to a broader more complex policy during the nineties. This latter policy has shown a marked tendency to intensify the city's cultural projection (ICUB-1996), through the promotion of large-scale events and the strengthening of the city's institutional networking in parallel with the development of the city's branding, directed by the public paradiplomacy and tourism sectors.

In this process new "recourses and constraints" (Logan et al. 1997) have shaped the internationalization policies, exacerbating local social and political tensions. Hence, the development, over more than two decades, of a major economic transformation linked to tourism and transnational investment that has fostered the reform of the city's cultural policy and which today represents a clear challenge for the successful management of the city's international image.

\section{Concluding remarks}

The present article has explored the origins and characteristics of the external cultural policies implemented by the city of Barcelona. In addition, it has examined the governmental and social dynamics in which this policy is embedded, within the broader context of the internationalization of the city's image. In so doing, it has analyzed the general attributes of cities' cultural paradiplomacies and the relations established with the goals and methods of branding. 
The political backdrop against which cities' cultural paradiplomacies have emerged has been characterized by a shift from a "nationally determined, locally relayed, welfare-oriented" policy to a "(supra-)nationally facilitated, locally determined, wide-ranging supply-side intervention" (Jessop 1997, p. 31). Indeed, the formation of multi-level governance and the diverse changes in state regulation and organization provide the background for this study.

During the 1980s, Barcelona experienced a major overhaul of its economy and infrastructure as the city was rapidly converted into a service economy. These processes generated the conditions that were favorable for attracting transnational capital and for promoting the city's cultural paradiplomacy, a key practice in this restructuring given the relevance acquired by culture in the contemporary world. After the 1992 Olympics, Barcelona's cultural policy was implemented in a context of social legitimacy, a strategy for economic and social development. During the decade following the games, the entrepreneurial turn taken by cultural policy and its marked economic and systemic trends served to reinforce a range of different internationalization projects in this field. Likewise, the international dimension of the urban culture also emerged as an attractive sector for the accumulation of political and economic capital.

The cultural paradiplomacy adopted by Catalonia has acquired a unique character because of its condition as a "stateless nation". Thanks to the establishment of the State of Autonomies, uncoordinated channels for the projection of an external identity have been created in a process that is inseparable from the pluri-national character of the State. As such, Catalonia's cultural policies have more often than not been partially subsumed to the promotion of a national identity (Villaroya 2009, Crameri 2008). Within this framework, a vital dimension for the institutionalization of cultural paradiplomacy in Barcelona has been the prevailing ethnic-national tension. Barcelona's cultural policy was immersed in the debate that sought to define the city's identity and embedded in multiple projects organized by different levels of government. In this context, the rich diversity of Barcelona's cultural paradiplomacy has served to place it on the map of global cities. At the same time, however, it has also gradually become an instrument for the construction of a new State, because of the growing importance of the movement for independence and the ongoing multi-party project within the Catalan parliament to "consult" the nation about its future. Hence, unlike the cities in other nations engaged in paradiplomacy around the world, including its counterparts in Brazil, Argentina and the US, Barcelona is an active participant in a 
dispute for the external representation and definition of its "national" character and this fact has served to boost its political actions and instrumentalizations.

In this sense, while internationalism, as Carlton Hayes (1955) has pointed out, supposes the existence of nationalism, internationalization does not. Therefore, cities that export culture as heritage or as arts, as ways of life, as part of city-branding projects, these cities can also act in a "postpolitical" way (Aronczyk 2009). However, the image that derives from these strategies can be connected symbolically to other identities and be subjected strategically to diverse political and economic goals. In this last regard, we understand that the effects of the transnationalization of the economy and the expansion of cultural branding make the practical and the theoretical delimitation of cultural paradiplomacy problematic. Moreover, they also impact the local cultural policy agenda, generating tension between culture understood as a social service and public issue and cultural goods as an image for commercial goals.

To sum up, both the outward appearance and the inherent characteristics of Barcelona's cultural paradiplomacy have been linked to changes in the international system and in international cultural policy; yet, at the same time, it has acquired its own specific character due to a State process of administrative decentralization, the impact of movements strengthening local identities (Mascarell 2007) and the pluri-national character of the State. All these elements have contributed to the overhaul of traditional cultural diplomacy in a progressive system characterized by policies that include central and sub-state activities, at times working to complement each other; at times in opposition (Criekemans 2010, p. 39). And while this trend can, on the one hand, result in the "loss of decisional and operational autonomy by state apparatuses (at whatever level) it can also enhance their capacity to project state power" (Jessop 1997, p. 33), but as Jessop (1997) points out: these changes in government structure can, furthermore, generate problems of governance failure, characterized by limited co-ordination and conflicting goals, something that, from the perspective of traditional cultural diplomacy, has already manifested itself in Barcelona's cultural paradiplomacy.

\section{Acknowledgments:}

The authors are most grateful to Professors Carla Figueira, Joaquim Rius Ulldemolins and Marc Pradel for their comments and recommendations. 


\section{Footnotes}

1 Specifically to the so-called "primacy of the executive" and the monopoly of state law in this area (Vilanova 1995).

${ }^{2}$ Catalonia operates seven government departments with the remit to undertake cultural paradiplomacy and runs seventy offices around the world. The latter include Government Delegations (not unlike embassies) and cultural entities such as the Ramon Llull Institute (IRL) with offices in Europe and the US and the Catalan Institute for Cultural Industries (ICEC) in Europe.

${ }^{3}$ This was most evident in the orientation given to this activity by pro-independence parties, above all during the government of the tripartite left-wing coalition in Catalonia (2003-2006), when this policy was managed by Esquerra Republicana de Catalunya. Indeed, it might be argued that cultural paradiplomacy was occasionally employed as a "protodiplomatic tool" i.e. an instrument defined for use in the international environment to manage external public opinion and to persuade other political actors with the goal of achieving independence (Duchacek 1990).

${ }^{4}$ In Spain, local government (city and provincial authorities) have significant managerial power in local cultural policy, the administration of local heritage, libraries (any territory with more than 5,000 inhabitants must be served by a library) and a range of artistic activities.

${ }^{5}$ It was ranked fourth among Europe's most visited cities in 2010, with five million visitors (Euromonitor International 2012).

${ }^{6}$ The Socialist Party of Catalonia linked to the Spanish national socialist party (PSOE). This organization enjoyed a position of hegemony at the local level of government in Catalonia for several decades. The successive Barcelona governments played a central role in defining Catalan cultural policies and in the democratization of access to culture.

${ }^{7}$ Ulldemolins identifies this as the beginning of a new approach to cultural policies, an approach based on the articulation of private and public participation (Rius 2003).

${ }^{8}$ For example, he was highly active in various multilateral institutions. Barcelona provided the seat for the formal constitution of the Eurocities network in 1989 (Borja 1997, p. 15). In 1992, Maragall was elected President of the Council of European Municipalities and Regions, where he played a tireless role, and, in 1996, he was elected President of the Committee of the Regions of the European Union.

9 The City Council participated in the creation and support of the Barcelona Center for International Affairs (CIDOB), Aula Barcelona, Fundación Casa América Cataluña, Instituto Barcelona de Estudios Internacionales (IBEI), and Instituto Europeo del Mediterráneo (IEMed).

${ }^{10}$ For example, in 2006 it participated in almost forty projects and networks aimed at promoting international cultural cooperation, including YOUROPE - the European Festivals Association, and Escity - Europe, Science and the City (ICUB 2006).

11 Barcelona also played host, from its foundation in 2004, to United Cities and Local Governments (CGLU) and is an active member of the UN's Advisory Committee of Local Authorities (UNACLA) and within various city networks and associations.

12 Among others, Barcelona participates in the Eurocities - Culture Forum; Initiatives in Dance through European Exchange (IDEE); International Network for Contemporary Performing Arts (IETM); South European Association for Contemporary Creation (IRIS) and International Federation of Library Associations and Institutions (IFLA).

13 These policies are strongly concentrated in Catalonia's metropolitan areas as is made evident by the survey conducted by the Observatory of Local Government 2012 (Observatory 2012).

14 In the case of Paris, the paradiplomacy of the city changed from complementing the Central State's foreign action to active self-promotion after 2001 (Jouve 2007, p.378). Actions of cultural paradiplomacy are implemented by the Direction des Affaires Culturelles and the General Delegation for International Relations and the General Delegation of Events and Protocol of the city council (www.paris.fr). These bodies organize programs to promote Parisian artists and the city's cultural institutions abroad and to foster cultural cooperation with other governments and diverse foreign actors. They also organize festivals with a clear international projection, such as the Nuit Blanche (copied by many cities), and are active in international networks (Ville Paris 2013, p.6). In Berlin, the Senate has promoted a range of 
actions to support art organizations and events of international dimensions, including the Berlin Biennale, and through its international promotion of the city's cultural industries, has even shown a tendency towards city branding (Jakob 2013, p. 177).

\section{References}

Acebal, Marc, 2008. Moviments socials i crítica al 'model barcelona'. de l'esperança democràtica de 1979 al miratge olímpic de 1992 i la impostura cultural del 2004, Scripta Nova, 11 (270).

Aja, Eliseo, 2007. El Estado Autonómico: Federalismo y hechos diferenciales. Madrid: Alianza Editorial.

Alonso, J.A.; Lozano, L., Prialé, M. A., 2004. La cooperación cultural española: más allá de la promoción exterior, Documentos de política, Instituto Complutense de Estudios Internacionales, 1.

Anholt, Simon, 2006. Competitive identity. Basingstoke: Palgrave Macmillan.

Anteproyecto Ley de Acción Exterior y Servicio Exterior del Estado. Ministerio de Asuntos Exteriores y Cooperación, 2013.

Ara, 2014. L'Ajuntament de Barcelona s'incorpora a l'Institut Ramon Llull i les Illes Balears se'n desvincula" 28 of January.Armiñan, Alfredo Pérez de, 2004. Reflexiones sobre la política cultural, Cuadernos de Pensamiento Político, 2, 217235.

Arndt, Richard, 2008. ¿Cultura o propaganda? Reflexiones sobre medio siglo de diplomacia cultural en Estados Unidos, Revista Mexicana de Política Exterior, 85, 29-54.

2007. The first resort of kings: American cultural diplomacy in the twentieth century. Washington: Potomac Books.

Aronczyk, Melissa, 2008. "Living the Brand": Nationality, Globality and the Identity Strategies of Nation Branding Consultants, International Journal of Communication, 2, 41-65.

2009. How to Do Things with Brands: Uses of National Identity, Canadian Journal of Communication, 34 (2) 291-295.

Balibrea, M. P, 2005. Barcelona: Del Modelo a la Marca. In: Jesús Carrillo; Ignacio Estella Noriega eds. Desacuerdos 3. Sobre Arte, Políticas y Esfera Pública en el Estado Español, Barcelona: Arteleku-MACBA-Universidad Internacional de Andalucía. 243-252) University of London.

Barba, Fabiola, 2008. Image Building: diplomacia cultural en la política exterior de Canadá, Revista Mexicana de Estudios Canadienses, 16

Barcelona Turisme, 2007. Congress Statistics Barcelona 2007. Bureau, Barcelona Convention. Barcelona.

Bélanger, Louis, 1994. La diplomatie culturelle des provinces canadiennes, Études internationales, 25 (3), 421-452.

Bianchini, Fr. 1993, Remaking European cities: the role of cultural policies, in Fr. Bianchichi \& M. Parkinson, Cultural policy and urban regeneration. The West European experience, Manchester: U.P. 
--Urban Cultural Policy in Britain and Europe: Towards Cultural Planning. London: Institute for Cultural Policy Studies.

Bonet, Lluis, 2001. Les polítiques culturals a Catalunya: un espai d'acords bàsics en un context d'alt dinamisme. In: $\mathrm{R}$ Subirats Gomà, J. ed, Govern i politiques públiques a Catalunya: Autonomia $i$ benestar. Barcelona: Universitat de Barcelona, Universidad Autónoma de Barcelona, 303-325.

Borja, Jordi, 1997. Las ciudades como actores políticos, América Latina Hoy, 15, 15-19. Bound, Kirsten, Rachel Briggs and John Holden 2007. Culture is a central component of international relations. It's time to unlock its full potential ... London: Demos.

Bouzada, Xan, 2007. La gouvernance de la culture en Espagne. In: L. Bonet; E. Négrier eds. La politique culturelle en Espagne. Paris: Karthala, 15-34.

Brenner, N, 2004. Urban governance and the production of new state spaces in western Europe 1960-2000, Review of International Political Economy, 11 (3), 447-488.

----------, 2003. La formación de la ciudad global y el re-escalamiento del espacio del Estado en la Europa Occidental post-fordista. Eure, 29 (86), 5-35.

Capel, Horacio, 2007. El debate sobre la construcción de la ciudad y el llamado 'Modelo Barcelona" [online]. Scripta Nova. Revista electrónica de geografía y ciencias sociales, 11 (233), 59. Available from: 〈http://www.ub.es/geocrit/sn/sn-233.htm> (Accessed 24 February 2009).

Carames, Esteve. 19 set. 2013, Barcelona. Mariano Martín Zamorano.Casellas, Antònia, Dot Jutgla, E. and Pallares- Barbera, M., 2010. Creación de imagen, visibilidad y turismo como estrategias de crecimiento económico de la ciudad, Finisterra, 45 (90), 153-172.

Castells, Manuel and Ollé, Esteve, 2004. El modelo Barcelona II: el ayuntamiento de Barcelona en la sociedad red. Informe de investigación (documento de sintesis).

Castells, Manuel, 1993. European cities, the informational society, and the global economy. Tijdschrift voor economische en sociale geografie, 84 (4), 247-253.

------------, 2009, Comunicación y poder. Madrid: Alianza.

------, 1997. La sociedad red. Madrid: Alianza.

Cherbo, J. M.; Wyszomirski, M. J.., 2000. The Public Life of the Arts in America. New Brunswick: Rutgers.

Ciurana, Jaume, 2011. Una politica cultural per Barcelona. Cercle de Cultura, 15.

Colino, C., 2007. La acción internacional de las comunidades autónomas y su participación en la política exterior española. Documento de Trabajo 10/2007. Madrid: OPEX. Fundación Alternativas.

Connolly, Mark Gerard, 2011. The 'Liverpool model(s)': cultural planning, Liverpool and Capital of Culture 2008. International Journal of Cultural Policy, 1-20.

Conseil des arts de Montréal, 2012. Plan stratégique 2013-2016. Montreal: Conseil des arts de Montréal.

Crameri, Kathryn, 2008. Catalonia: National Identity and Cultural Policy 1980-2003. Cardiff: University of Wales Press.

Criekemans, David, 2006. How subnational entities try to develop their own 'paradiplomacy'. The case of Flanders (1993-2005). Challenges for Foreign Ministries: Managing Diplomatic Networks and Optimising Value, Génova.

Perspective: Quebec, Scotland, Bavaria, Catalonia, Wallonia and Flanders. The Hague Journal of Diplomacy, 5, p. 37-64. 
Cubeles, X., ed., 1993. La Distribució territorial de la despesa en inversions reals $i$ transferències del Ministeri de Cultura (periode 1989-1992). Barcelona: Centre d'Estudis de Planificació.

Cull, Nicholas J. ed., 2009. Public Diplomacy: Lessons from the Past. Los Angeles: Figueroa Press.

Cummings, Milton C., 2003. Cultural Diplomacy and the United States Government: A Survey. Washington D.C: Center for Arts and Culture.

Departament de Vicepresidència. Afers Exteriors i Cooperació, Generalitat de Catalunya. Plá d'Acció Exterior del Govern de Catalunya 2010-2015. Barcelona.

Duchacek, Ivo D., Daniel Latouche and Garth Stevenson, 1998. Perforated sovereignties and international relations: trans-sovereign contacts of subnational governments. Westport: Greenwood Press.

Duchacek, Ivo. D., 1984. The international dimension of subnational self-government. Publius 14 (4), 5-31.

1990. Perforated sovereignties: toward a typology of new actors in international relations. In Soldatos, $\mathrm{P}$ and Michelmann, J. eds., Federalism and international relations: the role of subnational units. Nueva York: Oxford University Press.

Euromonitor, 2012, 'Euromonitor International's Top 100 City Destinations Ranking', Euromonitor International.

Evans, Graeme, 2003. Hard branding the cultural city. International Journal of Urban and Regional Research, 27 (2), 417-440.

Fina, Xacier and Subirats, Joan, 2011. Proximitat, cultura i tercer sector a Barcelona Barcelona: Icaria.

Flaquer, Lluis and Giner, Salvador, 1992. "Entre la esencia y la gerencia: la cultura catalana hoy", El Pais, 30 de Julio, sec. Tribuna.

Gabancho, Patricia, 2009. Barcelonisme contra catalanitat, una pugna perversa, Cultura 4 Barcelona, capital de la cultura catalana?, 12.

Garcha, A. 2007. Diplomatic Culture or Cultural Diplomacy: The Role for Culture in International Negotiation [online]. Available from: http://www.culturaldiplomacy.org/content/pdf/icd_diplomatic_culture_of_cultural _diplomacy (Accessed 05-06-2013).

Garcia, Beatriz, 2002. El concepte de programa cultural olímpic: orígens, evolució i projecció [online], Centre d'Estudis Olímpics (UAB). Available from: $<<$ http://olympicstudies.uab.es/cast/lectures/web/pdf/spa_garcia.pdf >, (Accessed 05-11-2012).

Garcia, Marisol, 2008. Barcelona: ciudadanos y visitantes. In: Garcia, Marisol Degen, Mónica eds. La metaciudad: Barcelona. Transformación de una metrópolis. Barcelona: Anthropos.

Germain, A. and D. Rose (2000). Montréal: The Quest for a Metropolis. Chichester, UK: Wiley. Chapter 7, "Language, Ethnic Groups and the Shaping of Social Space," pp. 213-53.

Giner, Salvador, 1996. La cultura catalana: el sagrat i el profà. Barcelona: Edicions 62.

Gouvernement du Québec, 2006, La politique internationale du Québec. La force de l'action concertée, Ministère des Relations internationals.

Harrison, Philip, 1995. Changing Cities, Global Economics, Urban Restructuring and Planning Response. Transformation: Critical Perspectives on Southern Africa, 28, $35-50$. 
Harvey, D., 1989. From Managerialism to Entrepreneurialism: The Transformation in Urban Governance in Late Capitalism. Geografiska Annaler.Series B, Human Geography, vol. 71, no. 1, pp. 3-17 ISSN 04353684

Hayes Carlton, 1955. The historical evolution of modern nationalism, New York,Macmillan

Hocking, B., 1993. Localizing Foreign Policy. Non-Central Governments and Multilayered Diplomacy. New York: St Martin's Press.

ICUB Ajuntament de Barcelona, (2012), Memòria l'Institut de Cultura de Barcelona, Barcelona.------------------- (2001-2010), Memòria l'Institut de Cultura de Barcelona, Barcelona.

Pla estratègic del sector cultural de Barcelona, 1999. Barcelona.

acentos, 2006. Barcelona.

Plan estratégico de cultura de Barcelona. Nuevos 2006, Memòria 2006, Barcelona.

Jakob, Doreen, 2013. "To Have and to Need": Reorganizing Cultural Policy as Panacea for 176 Berlin's Urban and Economic Woes, In: Grodach Carl and Silver Daniel, The politics of urban cultural policy global perspectives, Routledge.

Jessop, Bob, 1997. The entrepreneurial city: re-imaging localities, redesigning economic governance, or restructuring capital? In: Nick Jewson and Susanne MacGregor, eds., Transforming cities: contested governance and new spatial divisions. London: Routledge.

Jouve, Bernard, 2007. Urban societies and dominant political coalitions in the internationalization of cities, Environment and Planning C: Government and Policy, 25, 374 - 390.Keating, Michael, 2005. Gobernar las ciudades-región: Política, Economía y Desarrollo, Ekonomiaz: Revista vasca de economía, 58, 12845.

Kotler, Philip, Haider, Donald H. and Rein, Irving, 1993. Marketing Places: Attracting Investment, Industry, and Tourism to Cities, States and Nations. New York: The Free Press.

Lecours, André and Moreno, Andre (2003). Paradiplomacy and stateless nations: a reference to the Basque Country, Montreal: The Institute for Research on Public Policy.

Lecours, André, 2002. Paradiplomacy: Reflections on the Foreign Policy and International Relations of Regions, International negotiations, 7, 91-114.

Leonard, Mark, 2002. Public Diplomacy. London: Foreign Policy Centre.

Logan, J. Whaley, R and Crowder K, 1997, "'The character and consequences of growth regimes: an assessment of 20 years research" Urban Affairs Review 32 pp.603630Mannheim, J. B, 1994. Strategic Public Diplomacy \& American Foreign Policy. New York: Oxford University Press.

Maragall, Pasqual, 1992. BARCELONA'92. La culminación del reequilibrio urbano, Distribución y consumo., (2), 1.

Markets, FDI, 2011. FDI into Barcelona in Innovative and Creative Industries. Ontario: FDI Markets.

Marshall, Tim, 2004. Transforming Barcelona. London: Routledge.

Marx, Vanessa, 2008. Las ciudades como actores políticos en las relaciones internacionales. Thesis (PhD). Universidad Autónoma de Barcelona. 
Marzo, Jorge Luis and Badia, Tere. Las políticas culturales en el Estado español (19852005) [online]. Available from: http://www.soymenos.net. (Accessed 02-112012).

Massart-Piérard, F., (1999) 'Politique des relations extérieures et identité politique: la stratégie des entités fédérées de la Belgique', Études internationales, Vol. 30 : 701-727.

Mascarell, Ferran, 2007. Barcelona y la modernidad: La ciudad como un proyecto de cultura. Barcelona: Gedisa.

McNeill, Donald, 2001. Barcelona as Imagined Community: Pasqual Maragall's Spaces of Engagement, Transactions of the Institute of British Geographers, 26 (3), 340352.

1999. Urban Change and the European Left: Tales from the New Barcelona, London: Routledge.

Menger, P.-M. 2010 Cultural Policies in Europe. From a State to a City-Centered Perspective on Cultural Generativity, GRIPS Discussion Paper 10-28, Tokyo.

Milani, Carlos R., 2010. Relaciones internacionales y paradiplomacia en las ciudades brasileñas: la elaboración del concepto de "gestión internacional local, Geopolítica(s), 1 (1), 23'40.

Moragas i Spà, Miquel de, 2012. Communication, cultural identities and the Olympic Games: the Barcelona'92 experience [online], Available from: <http://olympicstudies.uab.es/pdf/wp006_eng.pdf>, (Accessed 06-10-2012). -(2008). La Olimpiada Cultural de Barcelona en 1992: Luces y sombras. Lecciones para el futuro [online]. Barcelona: Centre d'Estudis Olímpics UAB. Available from: http://olympicstudies.uab.es/pdf/wp049_spa.pdf, (Accessed 15-10-2012).

Negrier, E. 1997 French Cultural Decentralization and International Expansion.Towards a Geometrically Variable Interculturalism?, International Journal of Urban and Regional Research, 21, 1, 63-74.

Nofre I Mateo, Jordi, 2010. Políticas culturales, transformaciones urbanas e higienización social en la Barcelona contemporánea, Anales de geografía de la Universidad Complutense, 30, 133-61.

Nossal, Kim Richard, Stéphane Roussel et Stéphane Paquin, 2007. Politique internationale et défense au Canada et au Québec. Montréal: Presses de l'Université de Montréal.

Noya, J., 2003. Luces y sombras de la acción cultural exterior. Madrid: Real Instituto Elcano.

Nunes, C. J. da S., 2005. A paradiplomacia no Brasil: o caso do Rio Grande do Sul, Master Thesis. Universidade Federal de Rio Grande do Sul.

Obiols, Isabel, 1998. "Tres de cada cuatro ciudadanos de Barcelona no van nunca al teatro, a conciertos o a ver exposiciones", El Pais, 10-07.

Observatory Pi i Sunyer, 2012. The Foreign Affairs strategy of the Catalan local entities. Conclusions of the survey of the Local Government. Barcelona: Observatory of the Carles Pi i Sunyer Foundation for autonomic and local studies.

Otero, Jaime and Marco, Elvira, 2010. Colaboración público-privada en la acción cultural exterior" en Documento de Trabajo 3/2010, Real Instituto Elcano.

Palou Rubio, Saida, 2009. La ciudad fingida el caso de Barcelona. Abaco: Revista de cultura y ciencias sociales, 67-83.

Pascual, Jordi, 31 Jan. 2013, Barcelona Mariano Martín Zamorano. 
Paul Gérin-Lajoie, «La personnalité internationale du Québec - Le Québec est vraiment un État même s'il n'a pas la souveraineté entière», Le Devoir, 14 avril 1965,

Paquin, S., 2004. Paradiplomatie et Relations Internationales: théorie des stratégies internationales des régions face à la mondialisation. Bruselas: Presses Interuniversitaires Européennes.

Paschalidis, Gregory, 2009. Exporting national culture: histories of Cultural Institutes abroad, International Journal of Cultural Policy, 15 (3), 275-289.

Preteceille, Edmond, 1994. Paradojas políticas de las reestructuraciones urbanas, globalización de la economía y localización de lo político. In: Anna Alabart, Giner, Salvador and Garcia, Soledad. Clase, poder y ciudadanía. Madrid: Siglo XXI.

Pujol Jordi. 9 Jan. 2013, Barcelona. Mariano Martín Zamorano.

Ramoneda, Josep, 2011. 13 Tesis sobre la internacionalización de la cultura', In Instituto de cultura de Barcelona (ed.). Barcelona: Instituto de Cultura del Ayuntamiento de Barcelona.

Rius Ulldemolins, Joaquim, 2013. Culture and Authenticity in Urban Regeneration Processes: Place Branding in Central Barcelona', Urban Studies.

-2003. Un nou paradigma de la política cultural. Una recerca sociològica en curs sobre el cas barceloní, Revista Catalana de Sociologia, 219-228.

Rodríguez Morató, Arturo, 2012. The Culture Society: A Heuristic for Analyzing Cultural Change in the Global Age. In: Sales, Arnaud ed, Sociology Today: Social Transformations in a Globalizing World. London: Sage.

, 2007. La sociedad de la cultura. Barcelona: Ariel.

, 2005. La reinvención de la política cultural a escala local: el caso de Barcelona, Sociedade e Estado, 20 (2), 351-376. 1999. Estratègies culturals i renovació urbana. Barcelona: Aula Abierta.

Rubio Arostegui, Juan Arturo (2008). "Génesis configuración y evolución de la política cultural del estado a través del Ministerio de Cultura.: 1977-2007". RIPS: Revista De Investigaciones Políticas y Sociológicas, 7(1), 55-70.

Sassen, Saskia, 2007. Una sociología de la globalización. Buenos Aires: Katz.

Serra, Catalina, 2008. "El Fórum de las Culturas fue un fracaso porque la política de corto alcance ganó a la cultura". El País, March 28.

Simon, Cristina, 2006. Subvencions $i$ inversions nominatives en cultura als pressupostos generals de l'Estat. 2004-2006. Barcelona: Departament de Cultura.

Subirats, Joan and Brugue, Quim, 1997. El Govern de la ciutat i el desbordament de les lògiques territorials i institucionals', In: Joan Roca i Albert ed., El municipi de Barcelona i els combats pel govern de la ciutat. Barcelona: Institut de Cultura de Barcelona.

Subirós, Pep, 1994. El vol de la fletxa. Barcelona'92: Crònica de la reinvenció de la ciutat. Barcelona: Electa-Centre de Cultura Contemporània de Barcelona. Barcelona. 1999. Estratègies culturals $i$ renovació urbana. Barcelona: Aula

Vilanova, Pere, 1995. El Estado y el Sistema Internacional: Una aproximación al estudio de la política exterior. Barcelona: EUB.

Vilanova, Pere, 1995. El Estado y el Sistema Internacional: Una Aproximación al Estudio de la Política Exterior. Barcelona: EUB. 
Villarroya Planas, Anna, 2011. Cultural policies and national identity in Catalonia, International Journal of Cultural Policy, 18 (1), 31-45.

Ville Paris, 2013. Action Internationale. Raport d'Activites, Paris.Zaharna, S. Rhonda, 2009. Mapping Out a Spectrum of Public Diplomacy Initiatives. In: Nancy Snow and Philip Taylor eds., Routledge Handbook of Public Diplomacy. New York: Routledge, 86-100.

Zukin, S, 1995. The Cultures of Cities. Cambridge: Blackwell.

Table 1. Main activities in the cultural paradiplomacy of ICUB (2001-2010)

\begin{tabular}{|c|c|}
\hline Year & Activity \\
\hline 2001 & Active member of Culture Committee of Eurocities \\
\hline 2002 & Gaudi International Year 2002 (joint project organized by the Autonomous and Central Governments) \\
\hline 2003 & $\begin{array}{r}\text { "Agenda 21" with Porto Alegre City Council } \\
\text { Exportation of MACBA exhibition and SONAR festival }\end{array}$ \\
\hline 2004 & $\begin{array}{r}\text { European Film Awards of European Film Academy } \\
\text { Host of United Cities } \\
\text { Universal Forum of Cultures }\end{array}$ \\
\hline 2005 & $\begin{array}{r}\text { Participation in Working Group "Agenda 21" United Cities and Local Governments } \\
\text { Presidency of Cultural Network of Eurocities } \\
\text { Final conference of Eurocult } 21 \text { Project } \\
\text { Year of Books and Reading at Book Fair in Guadalajara }\end{array}$ \\
\hline 2006 & $\begin{array}{r}\text { Exhibition Gaudí. Geneva (History Museum of City and Central Government) } \\
\text { Working Group on Culture/United Cities and Local Governments } \\
\text { Consortium of libraries. Cooperation with libraries of Mediterranean region/ MEDACT }\end{array}$ \\
\hline 2007 & $\begin{array}{r}\text { Committee on Culture - United Cities and Local Governments } \\
\text { Forum of Cultures /Eurocities } \\
\text { Barcelona \& Modernity. Gaudí to Dalí, Metropolitan Museum of Art, New York } \\
\text { Cosmos Gaudí (with the collaboration of the Central Government) }\end{array}$ \\
\hline 2008 & $\begin{array}{r}\text { European Year of Intercultural Dialogue } \\
\text { Committee on Culture - United Cities and Local Governments }\end{array}$ \\
\hline 2010 & Presidency renewal of Committee on Culture - United Cities and Local Governments \\
\hline
\end{tabular}

Source: ICUB memòries, 2001-2010 